\title{
APLIKASI MODEL COMPONENT DISPLAY THEORY (CDT) DALAM PENGEMBANGAN MULTIMEDIA INTERAKTIF MATAKULIAH JARINGAN KOMPUTER.
}

\author{
Rr. Eny Kuswandari, Suryanto \\ PPs UNY, FMIPA Universitas Negeri Yogyakarta \\ eny@uny.ac.id
}

\begin{abstract}
Abstrak
Tujuan penelitian ini adalah: (1) menghasilkan produk program pembelajaran multimedia interaktif berbasis CDT yang diharapkan dapat membantu mahasiswa dalam memahami materi mata kuliah Jaringan Komputer sesuai skill yang diharapkan; (2) menguji kelayakan media pembelajaran ditinjau dari aspek isi/materi, media dan pembelajaran. Metode penelitian ini merupakan penelitian dan pengembangan (research and development). Pengembangan multimedia ini dilakukan melalui tahapan: analisis, desain, pengembangan, evaluasi dan revisi. Data dikumpulkan melalui kuesioner dan observasi. Data berupa hasil penilaian melalui kualitas produk, saran untuk perbaikan produk, serta data kualitatif lainnya. Data kuantitatif dianalisis dengan statistik deskriptif. Saran-saran yang diperoleh digunakan sebagai dasar untuk merevisi produk. Hasil penelitian adalah: (1) produk program pembelajaran multimedia interaktif mata kuliah Jaringan Komputer berbasis CDT (Component Display Theory) dalam bentuk CD yang memiliki kelayakan kriteria baik dari aspek isi/materi, media, dan pembelajaran. Aplikasi model Component Display Theory (CDT) dalam pengembangan multimedia interaktif yang digunakan dalam penelitian ini memiliki kelayakan kriteria baik digunakan dalam proses pembelajaran mata kuliah Jaringan Komputer.
\end{abstract}

Kata kunci: CDT, pengembangan multimedia interaktif, Jaringan Komputer

\section{APPLICATION OF COMPONENT DISPLAY THEORY (CDT) IN DEVELOPING INTERACTIVE MULTIMEDIA FOR COMPUTER NETWORKS INSTRUCTION}

\author{
Rr. Eny Kuswandari, Suryanto \\ PPs UNY, FMIPA Universitas Negeri Yogyakarta \\ eny@uny.ac.id
}

\begin{abstract}
The aims of this research are:(1) to develop computer-based instructional media CDT based for Computer Network instruction, and; (2) to reveal the quality of the developed instructional media viewed from the aspect of content, media and instruction. This research was a development research. The process of developing the multimedia was in the stage of instruction, analysis, design, development, evaluation and revision. The data were collected using a questionnaire and observation. The data were in the form of the result of the evaluation on the quality of the product, recommendation for the product improvement and other qualitative data. The result of this research is computer-based instruction media for Computer Network instruction in the form as a compact disc (CD). Therefore it can be concluded that the multimedia developed in this study are appropriate for the teaching of computer networks.
\end{abstract}

Keywords:CDT, Component Display Theory, interactive multimedia, Computer network 


\section{Pendahuluan}

Perkembangan ilmu pengetahuan dan teknologi, menuntut dan mendorong pertumbuhan pendidikan di Indonesia. Mata kuliah Jaringan Komputer termasuk memiliki peranan penting dalam menunjang kemajuan ilmu pengetahuan dan teknologi, yang merupakan tantangan untuk meningkatkan kualitas pembelajaran. Mata kuliah Jaringan Komputer diajarkan di Jurusan Pendidikan Matematika Fakultas Matematika dan Ilmu Pengetahuan Alam Universitas Negeri Yogyakarta (FMIPA UNY). Mata kuliah Jaringan Komputer merupakan mata kuliah yang mendasari mata kuliah aplikasi komputer dan aplikasi matematika dalam komputer program studi pendidikan matematika sesuai dengan kurikulum 2013 yang diselenggarakan untuk menghasilkan tenaga pendidik yang profesional di bidang matematika untuk sekolah menengah, baik SMA maupun SMK. Untuk itu mahasiswa prodi pendidikan matematika diharapkan tidak hanya mampu menguasai materi jaringan komputer sebagai prasyarat mata kuliah tetapi juga mampu mengajarkannya kepada siswa di sekolah menengah agar lulusan prodi pendidikan Matematika mampu menguasai materi jaringan komputer secara lengkap dan mendalam.

Dengan memanfaatkan kemajuan teknologi informasi dan komunikasi dalam pembelajaran, diharapkan dapat membantu memecahkan masalah belajar yang dihadapi mahasiswa. Penggunaan komputer multimedia dan internet sudah mulai banyak digunakan dalam pembelajaran. Hal ini dilakukan karena berbagai studi menunjukkan Mevarech, dkk. (1987) bahwa program pembelajaran yang dirancang dengan menggunakan komputer lebih efektif dibandingkan dengan paket pengajaran lainnya, karena komputer memiliki sejumlah potensi yang dapat dimanfaat untuk meningkatkan efektivitas proses pembelajaran.

Dalam proses pembelajaran diperlukan media pembelajaran yang dapat membantu memberikan penjelasan terhadap materi yang diajarkan, sehingga pemahaman mahasiswa terhadap materi semakin dalam, ada beberapa materi pada jaringan komputer sangat memerlukan multimedia bukan sekedar gambar atau teks saja untuk menyampaikan dan memvisualisasikan proses dan contoh. Sebagai misal penyampaian simulasi materi jaringan komputer agar mahasiswa mudah memahami dan pembelajaran menjadi lebih bermakna.

Berdasarkan uraian di atas, perlu dikembangkan program pembelajaran mul-timedia interaktif untuk itu penulis perlu merancang dan diproduksi CD pembelajarandengan multimedia interaktif yang diharapkan dapat meningkatkan kemampuan kognitif mahasiswa mengenai materi mata kuliah Jaringan Komputer. Dengan pembelajaran multimedia interaktif diperlukan desain Pembelajaran yang cocok karena media pembelajaran multimedia sifatnya adalah suplemen, artinya ia hanya mendukung kuliah di kelas maka diperlukan langkah-langkah sistematik dalam pengembangan desain pembelajaran termasuk dalam mengidentifikasi tujuan pembelajaran (learning objectives).

Dengan Pembelajaran multimedia interaktif dalam perencanaan memerlukan suatu teori desain instruksional atau Instructional Design Theory yaitu preskripsi (prescription) bagaimana menyusun strategi pembelajaran agar tujuan pembelajaran tercapai. Dengan demikian strategi pembelajaran bekenaan dengan pendekatan dalam mengelola kegiatan pembelajaran untuk menyampaikan materi atau isi pelajaran secara sistematik, sehingga kemampuan yang diharapkan dapat dikuasai oleh mahasiswa secara efektif dan efisien, termasuk didalamnya adalah pemilihan media. Dalam penelitian ini penulis menggunakan multimedia sedangkan dalam teori desain instruksional dalam penelitian ini penulis menggunakan teori desain pembelajaran M.David Merrill yaitu Component Display Theory (CDT) untuk desain multimedia interaktif. Salah satu aspek CDT adalah 
taksonomi yang terdiri atas performance dan content. Dalam hal ini mahasiswa diharapkan mampu mengingat (remember), mengaplikasikan (use) atau menemukan (find) dari suatu content yang merupakan materi pembelajaran yang berisi fakta (facts), konsep (concept), prinsip (principle) atau prosedur (procedure). Merrill (1994: p.111) dalam khasanah teori pembelajaran, Component Display Theory (CDT) mempunyai komponen-komponen penting dalan Instructional Design Theory (IDT) yaitu :(1) deskripsi teori tentang pengetahuan dan skill yang diharapkan yaitu matriks contentperformance; (2) deskripsi teori tentang strategi instruksional yaitu mengembangkan strategi instruksional CDT mempunyai 3 komponen strategi yaitu primary presentation forms (PPF), secondary presentations forms (SPF) dan interdisplay relationships (IDRs). Dengan menggunakan komponen-komponen dalam suatu matriks akan memudahkan menentukan tujuan pembelajaran; (3) formulasi bagaimana mengkorelasikan atau menghubungkan content performance dengan PPF, SPF dan IDRs.

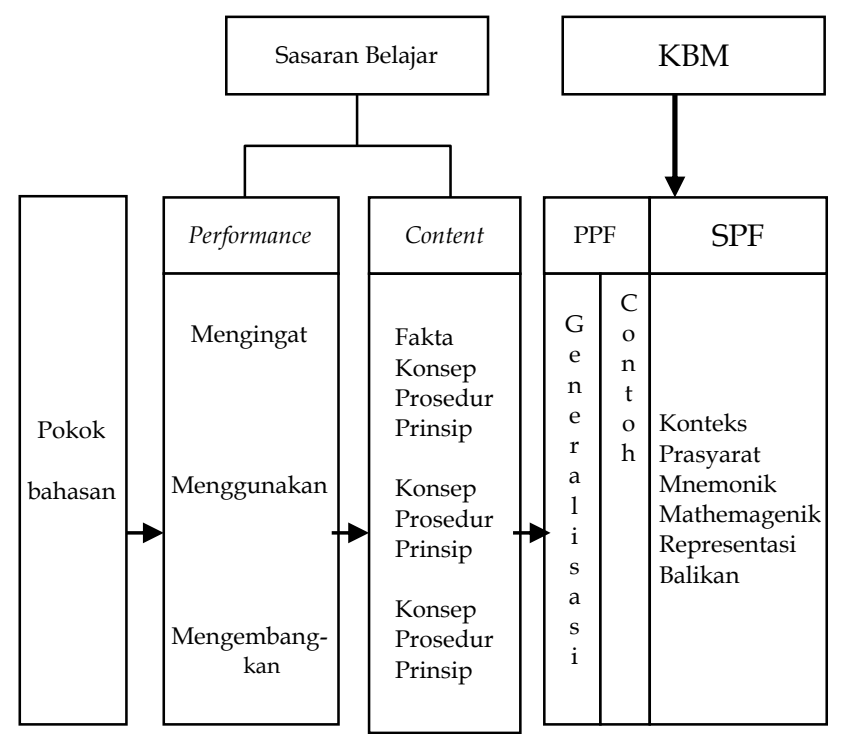

Sumber: Gatot Pramono S. (2007

\section{Gambar 1. Preskripsi untuk CDT}

Hubungan matriks content-performance dan PPF serta SPF ditunjukkan pada Gambar 1. Setelah menentukan tipe pengetahuan dan performance yang diinginkan melalui matriks content-performans, serta mengidentifikasi langkah-langkah instruksional melalui PPF, SPF dan IDR maka langkah selanjutnya adalah menggabungkan kedua hal di atas melalui suatu prosedur untuk mendapatkan suatu preskripsi atau formula bagi desain instruksional. Prosedur ini mencakup bagaimana mengatur urutan dari expository dan inquiry, memilih tipe-tipe PPF yang sesuai dan menentukan bagaimana perubahan tampilan (display) melalui IDR.

Setelah preskripsi untuk desain instruksional paripurna maka langkah selanjutnya adalah mengaplikasikannya dalam media yang dipilih. Dalam hal ini media yang dipilih adalah komputer (multimedia).

Salah satu ciri CDT ialah kemampuannya untuk menghasilkan tingkat kecermatan yang tinggi dalam mencapai sasaran belajar. Melalui akumulasi penguasaan sejumlah sasaran belajar yang dirancang secara cermat, mahasiswa terbantu untuk berpikir secara runtut, kritis, dan sistematis. Di samping itu, melalui program pembelajaran yang dikembangkan dengan menggunakan CDT ini, akan dipandu dalam memilih dan menggunakan metode yang tepat. Dari sekian banyak teori desain instruksional mulai dari teori Gagne-Briggs, Gropper, Component Display Theory (CDT), teori Elaborasi, hingga teori ARCS, penulis mencoba mencari-cari teori mana yang cocok diaplikasikan dalam pengembangan pembelajaran di dalam media yang dinamis seperti multimedia pembelajaran dan internet. Pilihan penulis jatuh pada CDT dengan pertimbangan pertama : diantara teori-teori lain teori ini yang paling lengkap strategi mikronya. Kedua penentuan tujuan pembelajaran (taksonomi) melalui apa yang disebut matriks performance-content sangat sederhana dan mudah. Disamping itu taksonomi ini merupakan bagian integral dari CDT itu sendiri sehingga preskripsi bagi materi yang akan ditampilkan sangat terkait erat dengan tujuan pembelajaran yang telah ditetapkan. Ketiga cara pengaturan tampilan (display) yang dipreskripsikan oleh CDT 
sangat cocok untuk diaplikasikan dalam multimedia pembelajaran termasuk pada mata kuliah Jaringan Komputer di Jurdik Matematika FMIPA UNY. Teori ini pernah diaplikasikan di dalam suatu program pembelajaran yang disebut TICCIT (TimeShare, Interactive, Computer-Controlled Information Television) yang dikembangkan oleh suatu tim yang dipimpin oleh Dr. David Merill, penemu teori ini pada tahun 1970an.

Dengan Pembelajaran multimedia interaktif berbasis CDT diharapkan dapat menumbuhkan apresiasi dan persepsi yang positif mahasiswa terhadap mata kuliah Jaringan Komputer, serta lebih termotivasi dan mandiri dalam proses pembelajaran dalam mencapai tujuan pembelajaran secara efektif dan efisien.

Dari uraian latar belakang di atas dapat diidentifikasi beberapa permasalahan yang terjadi, yaitu: (1) mahasiswa seharusnya memahami materi mata kuliah Jaringan Komputer; (2) mahasiswa seharusnya memiliki kemandirian dalam belajar dan menganggap guru/dosen sebagai satu-satunya sumber belajar; (3) seluruh proses pembelajaran masih dilakukan dengan sistem konvensional dengan sumber belajar dan media yang terbatas. Karena ada materi yang harus disampaikan dengan simulasi tidak hanya teks atau gambar saja; (4) kebanyakan proses pembelajaran masih dilakukan dengan sistem konvesional dengan sumber belajar dan media yang terbatas teks atau gambar saja, sehingga materi yang bersifat prosedur dan aplikasi konsep menjadi sulit dipahami mahasiswa; (5) Belum tersedia sumber belajar mandiri dalam bentuk multimedia interaktif untuk mata kuliah Jaringan Komputer

Masalah difokuskan pada belum tersedianya multimedia interaktif berbasis Component Display Theory (CDT) pada mata kuliah Jaringan Komputer materi yang disampaikan dalam bentuk simulasi untuk membantu memudahkan sehingga mahasiswa mencapai pengetahuan dan skill yang diharapkan.
Berdasarkan permasalahan di atas selanjutnya masalah dirumuskan sebagai berikut: (1) bagaimanakah cara dan hasil pengembangan multimedia interaktif berbasis Component Display Theory (CDT) pada mata kuliah Jaringan Komputer?; (2) bagaimana kelayakan multimedia interaktif berbasis Component Display Theory (CDT) yang dikembangkan pada mata kuliah Jaringan Komputer dari aspek media, isi/ materi dan pembelajaran?

Penelitian ini bertujuan: (1) menghasilkan produk multimedia interaktif berbasis CDT yang diharapkan dapat membantu mahasiswa dalam memahami materi mata kuliah Jaringan Komputer sesuai skill yang diharapkan, (2) menguji kelayakan multimedia pembelajaran interaktif berbasis Component Display Theory (CDT) pada mata kuliah Jaringan Komputer ditinjau dari aspek isi/materi, media dan pembelajaran.

Produk yang diharapkan dari hasil penelitian dan pengembangan atau dikenal dengan Research and Development (REDini berupa software pembelajaran berbantuan komputer dengan multimedia interaktif untuk mata kuliah Jaringan Komputer, spesifikasi produk meliputi : (1) produk berupa program pembelajaran multimedia interaktif Jaringan Komputer yang yang dalam perancangannya menggunakan teori instruksional Component Display Theory (CDT); (2) program pembelajaran multimedia interaktif untuk pembelajaran Jaringan Komputer ini berfungsi sebagai media untuk menyampaikan materi baru, meskipun demikian program ini bukan merupakan media utama melainkan pelengkap dari penyampaian materi dengan menggunakan media lain; (3) program pembelajaran multimedia interaktif ini dibuat dalam bentuk kepingan Compact Disc (CD-ROM) yang dikembangkan dari aspek isi/materi, media dan pembelajaran sehingga dapat digunakan untuk pembelajaran individu maupun kelompok, kepingan $C D$ tersebut hanya dapat digunakan dengan perangkat computer yang memiliki CD ROM drive atau VCD (Video Compact Disc). Apabila 
digunakan dalam ruang kelas ditambah dengan media LCD (Liquid Crystal Display) Projector.; (4) program pembelajaran multimedia interaktif ini dibuat dalam bentuk kepingan Compact Disc (CD-ROM) sehingga dapat digunakan untuk pembelajaran individu, karena dapat dibawa pulang oleh mahasiswa. Kepingan $C D$ tersebut hanya dapat digunakan dengan perangkat komputer yang memiliki CDROMdrive atau VCD (Video Compact Disc). Apabila digunakan dalam ruang kelas ditambah dengan media LCD (Liquid Crystal Display) Projector.

Produk ini dirancang agar dapat memudahkan siswa dalam belajar karena memuat beberapa komponen, yaitu: (1) deskripsi singkat tentang pentingnya mata kuliah Jaringan Komputer sebagai prasyarat mata kuliah selanjutnya, (2) materi didesain dengan memperlihatkan petunjuk dengan menampilkan contoh kerja, ilustrasi dan bahan penarik perhatian berupa antara lain: warna, musik pengiring, suara, desain grafis, dan animasi serta video yang dapat menumbuhkan minat belajar dan meningkatkan pemahaman materi Jaringan Komputer, (3) learning objectives (tujuan pembelajaran), (4) isi materi, (5) soal latihan dan balikan, serta (6) rangkuman. Persyaratan yang harus dipenuhi agar produk dapat dioperasikan seperti RAM minimal $64 \mathrm{MB}$, monitor minimal VGA dengan resolusi minimal $800 \times 600$ pixel, CD ROM, sound card dan speaker

Hasil penelitian ini diharapkan dapat bermanfaat baik bagi mahasiswa, peneliti, maupun lembaga serta pihak lain yang memerlukan. Manfaat bagi mahasiswa, dapat memanfaatkan hasil penelitian ini terutama produk pembelajarannya, untuk membantu mereka dalam proses pembelajaran, yaitu membantu memahami materi mata kuliah Jaringan Komputer. Dengan produk tersebut kegiatan belajar menjadi lebih menarik dan sesuai dengan kemampuan masing-masing mahasiswa. Selain itu dengan memanfaatkan produk tersebut mereka dapat mengenal program pembelajaran berbantuan komputer, dimana hal ini sangat bermanfaat bagi mereka sebagai calon guru dalam peningkatan keefektifan pembelajaran. Selanjutnya manfaat bagi peneliti dapat memberikan pengalaman yang sangat berharga yang nantinya dapat diterapkan di tempat kerja. Melalui penelitian ini peneliti dapat belajar bagaimana mengembangkan teknologi pembelajaran yaitu merancang program pembelajaran multimedia interaktif berbasis Component Display Theory (CDT) dan mengembangkan/memproduksi CD pembelajaran yang mana pengalaman ini sangat dibutuhkan penulis. Selain itu, pengalaman tersebut juga bermanfaat bagi peneliti di masa mendatang untuk mengembangkan produk pembelajaran selanjutnya. Manfaat penelitian ini bagi lembaga khususnya di Program Studi Pendidikan Matematika mengingat program pembelajaran multimedia interaktif berbasis CDT belum dikembangkan. Program pembelajaran multimedia interaktif ini juga dapat dijadikan referensi dalam melakukan inovasi pembelajaran di program studi yang lain dalam mengembangkan teknologi pembelajaran dalam rangka meningkatkan kualitas pembelajaran.

Software pembelajaran multimedia interaktif ini dikembangkan berdasarkan beberapa asumsi: (1) pengembangan program ini dapat membantu mengatasi masalah belajar yang dihadapi mahasiswa terutama dalam memahami materi Jaringan Komputer dan untuk meningkatkan kemampuan kognitif maupun psikomotor, (2) pengembangan program ini dapat digunakan oleh mahasiswa dengan karakteristik/kemampuan yang berbeda-beda baik untuk pembelajaran di kelas maupun mandiri; (3) pengembangan program ini dapat meningkatkan motivasi, prestasi, kemandirian belajar, serta menciptakan sikap dan persepsi yang positif pada mata kuliah Jaringan Komputer, (4) program dikembangkan karena memiliki beberapa kelebihan dibandingkan jenis media yang lain dalam mengatasi masalah belajar yang ada.

Produk yang dihasilkan dari penelitian pengembangan ini memiliki beberapa keterbatasan, antara lain: (1) program ini 
hanya memuat materi Mata Kuliah Jaringan Komputer dan juga hanya mencakup beberapa pokok bahasan saja, dan (2) produk yang dihasilkan kemungkinan belum optimal karena adanya beberapa keterbatasan pada penulis, seperti waktu, kemampuan, dan dana.

Beberapa istilah yang perlu dijelaskan agar tidak menimbulkan kesalahpahaman oleh pembaca adalah sebagai berikut. Pertama, program pembelajaran multimedia interaktif adalah program/software pembelajaran interaktif yang dibuat dengan program aplikasi computer Adobe Flash CS 1 disimpan dalam keping CD, berisi materi kuliah Jaringan Komputer dan diakses/ditayangkan melalui bantuan computer, program ini dapat digunakan untuk pembelajaran individu maupun kelompok.

Kedua, pengembangan merupakan proses pembuatan (mendesain, memproduksi, mengevaluasi) bahan pembelajaran dalam wujud fisik yaitu software pembelajaran dengan komputer multimedia. Ketiga mata kuliah Jaringan Komputer merupakan salah satu mata kuliah pada Pogram Studi Matematika sebagai mata kuliah prasyarat mata kuliah selanjutnya yang diberikan untuk mahasiswa semester satu. Oleh karena itu mata kuliah ini berisi pengenalan konsep-konsep Jaringan Komputer dan prinsip-prinsip dalam mata kuliah Jaringan Komputer.

\section{Metode Penelitian}

Jenis penelitian ini adalah penelitian dan pengembangan atau dikenal dengan Research and Development (RED). Pengertian penelitian dan pengembangan berorientasi pada produk. Pada penelitian ini menghasilkan suatu produk berupa program pembelajaran multimedia interaktif berbasis CDT untuk mata kuliah Jaringan Komputer.

Subjek uji coba atau responden untuk setiap tahap yang terlibat adalah mahasiswa yang mengambil mata kuliah pilihan jaringan komputer Program Studi
Pendidikan Matematika FMIPA UNY. Untuk tahap uji coba kelompok kecil yang terlibat sebanyak 3 orang mahasiswa dan uji coba lapangan sebanyak 15 mahasiswa.

Penelitian dilaksanakan pada mata kuliah Jaringan Komputer semester genap Tahun 2014 pada Jurusan Pendidikan Matematika UNY

Model pengembangan dalam penelitian ini adalah model prosedural. Model prosedural adalah model yang bersifat deskriptif, yaitu menggariskan langkah-langkah yang harus diikuti untuk menghasilkan produk.

Sedangkan untuk desain software pembelajaran berbantuan komputer dipilih dengan memperhatikan 3 aspek yaitu functional design, physical design, dan logical design. Seperti telah diuraikan pada kajian pustaka, pada aspek desain fungsional dipilih tutorial design dan drill and practice design, karena sesuai untuk karakteristik materi Jaringan Komputer. Pada aspek fisik dipilih kombinasi desain cabang dan pengulangan, karena mampu mengindividualisasikan pembelajaran sehingga pebelajar mengalami pengalaman belajar sesuai dengan kecepatan belajar dan memberikan jalan alternatif dalam pembelajaran, serta memungkinkan pebelajar mengulang kembali materi dan latihan apabila mereka menghendaki. Sedangkan pada aspek logika, dipilih model deduksi (rules diikuti examples atau RULEG).

Model pengembangan produk pembelajaran menggunakan model rancangan system pembelajaran atau Instructional System Design (ISD yang dikembangkan oleh Fenrich (1997) yang terdiri dari langkahlangkah: (1) Analisis (Analysis), (2) Desain (Design), (3) Pengembangan (Development), (4) Implementasi (Implementation), (5) Evaluasi (Evaluation).

\section{Prosedur Pengembangan}

Prosedur pengembangan menggunakan model sistem instruksional desain atau Instructional System Design (ISD) Fenrich (1997, p.51) sebagai berikut: 
Analisis

Sistem instruksional desain berawal dari fase analisis. Pada fase ini pengembang instruksional menentukan topik apa yang diberikan serta memutuskan media apakah yang digunakan dalam instruksi yang akan diberikan. Setelah topik dan media yang akan digunakan ditentukan dengan alasannya yang reasonable maka langkah berikutnya adalah menentukan instructional goal (tujuan instruksional umum) dan learning objectives (tujuan instruksional khusus). Bila perlu analisis biaya (cost analysis) dibuat dan hambatanhambatan yang mungkin menghadang.

Aktivitas dalam fase analisis meliputi: (1) menentukan topik, (2) menentukan media utama yaitu multimedia, (3) menentukan instructional goal, (4) menentukan learning objectives dengan menggunakan taksonomi Merrill (performance- content), (5) estimasi biaya (bila perlu), dan (6) mendata masalah-masalah yang mungkin menghadang misal kesulitan membuat animasi atau video.

Desain

Berdasarkan learning objectives yang telah ditentukan maka pada fase desain disusun instructional strategies. Berdasarkan instructional strategies flowchart (navigasi) atau alur dari program yang telah ditentukan, yang juga penting adalah masalah penentuan user interface (graphical user interface) karena baik tidaknya suatu multimedia tergantung pada Graphical User Interface (GUI).

Aktivitas dalam fase desain meliputi: (1) menyusun instructional strategies menggunakan teori preskripsi dari Merrill, (2) menentukan flowchart (navigasi) dari program, (3) memilih media-media tertentu dalam program yang akan dibuat, misal bagian mana yang memerlukan animasi, suara, teks, simulasi atau video dan (4) merancang graphical user interface yaitu merancang bagaimana bentuk menunya, berapa level menu yang digunakan, bagaimana bentuk feed backnya dll.
Pengembangan

Berdasarkan instructional strategies, flowchart, dan GUI yang telah dirancang pada fase desain maka naskah (story board) ditulis pada fase pengembangan. Pada fase pengembangan pula pemrograman (coding) dilakukan. Aktivitas dalam fase pengembangan meliputi: (1) menulis naskah (story board), (2) membuat flowchart pemrograman atau UML (Universal Modelling Language) suatu metode untuk merancang pemrograman yang menggunakan OOP (Object Oriented Programming), (3) pemrograman multimedia, (4) membuat animasi, simulasi atau video yang diperlukan.

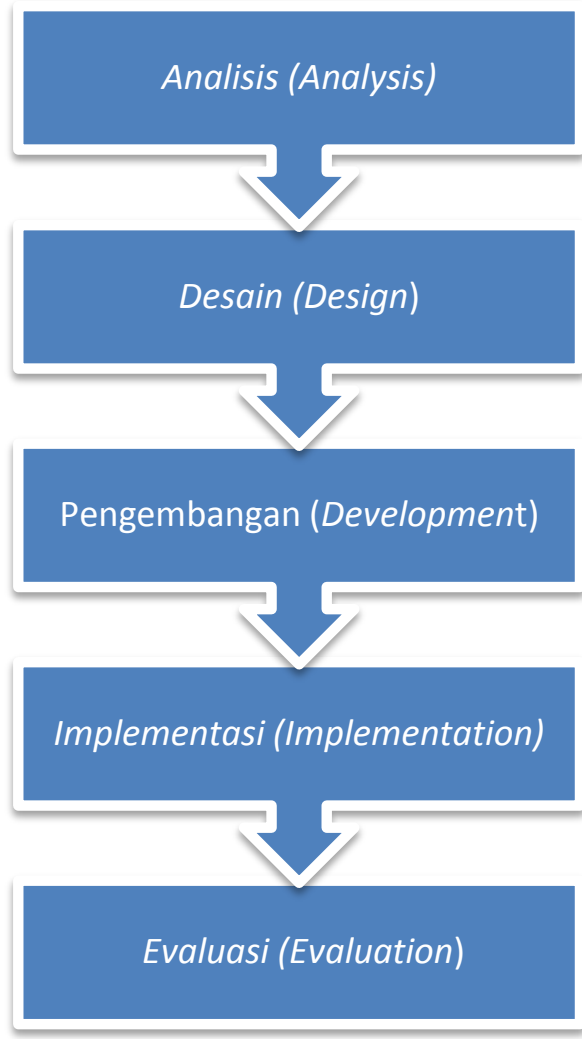

Gambar 2. Bagan Prosedur Pengembangan

Implementasi

Setelah program selesai dibuat maka saatnya program diuji coba kepada pengguna. Fase implementasi merupakan fase uji coba ini. Perbaikan program juga dilakukan pada fase ini. Perbaikan mungkin meliputi perbaikan dari desain maupun pemrograman itu sendiri. 
Aktivitas dalam fase implementasi meliputi: (1) uji coba prototipe di lapangan, (2) pendataan kelemahan dan kelebihan dari program dan (3) memperbaiki program sesuai temuan di lapangan.

Evaluasi

Setelah melalui tahap implementasi dimana beberapa perbaikan dan penyesuaian telah dilakukan maka saatnya melakukan evaluasi sejauh mana program multimedia yang dibuat memang membantu siswa (pengguna) dalam pembelajaran. Pada fase ini survei dilakukan untuk melihat kelebihan dan kelemahan dalam proses pembelajaran.

\section{Expert Judgement}

Expert judgement atau pertimbangan ahli dilakukan melalui validasi dari ahli materi dan ahli media.

\section{Uji Coba Produk}

Uji coba produk ini bertujuan untuk mengetahui apakah produk yang dibuat layak digunakan atau tidak dilihat dari kesesuaian dengan pengguna untuk menyelesaikan masalah pembelajaran. Uji coba, untuk melihat sejauh mana produk yang dibuat dapat mencapai sasaran dan tujuan. Produk yang baik memenuhi 2 kriteria: kriteria pembelajaran (instructional criteria) dan kriteria penampilan (presentation criteria). Uji coba dilakukan 3 kali yang mencakup uji-ahli, uji terbatas yang dilakukan terhadap kelompok kecil sebagai pengguna produk dan uji-lapangan (field testing).

\section{Jenis Data}

Data yang diperlukan dalam penelitian ini diperoleh dari berbagai sumber yaitu ahli materi, ahli media dan mahasiswa. Data tersebut berupa data kuantitatif dan kualitatif yang merupakan hasil penilaian kualitas program multimedia yang dikembangkan serta masukan sebagai dasar untuk melakukan revisi program.
Berikut ini disajikan berbagai data yang diperlukan dalam penelitian ini, beserta komponen penilaian dan indikator-indikatornya yang dirumuskan berdasarkan kriteria-kriteria penilaian yang dikembangkan oleh beberapa ahli yang dirujuk oleh penulis yakni antara lain Lee \& Owens (2004), Rob Philips (1997), Allessi \& Trollip (2001), Hanafin \& Peck (dalam Kennedy, 1998), Kennedy Petrofic \& Keppel (1998), Duarte (2000), Walker \& Hess (1984), Hackbarth (2000) dan Ade Koesnandar (2004).

Kualitas aspek/isi materi pembelajaran terdiri dari: (1) kebenaran materi dan keterkinian materi yaitu kebenaran secara keilmuan dan keselarasan isi dengan nilai yang dianut oleh masyarakat, (2) kecukupan materi untuk mencapai kompetensi, yang mengacu pada sisi keluasan dan kedalaman materi serta keutuhan konsep yang dapat mengantar siswa untuk mencapai kompetensi yang diharapkan, (3) ketercernaan sumber belajar dan pemaparan yang logis yang dapat mencakup penyajian materi yang runtut, (4) penggunaan bahasa yang meliputi pemilihan ragam bahasa, pemilihan kata, penggunaan kalimat, dan penyesuaian paragraf sehingga bahasa lugas, jelas dan tepat, (5) tampilan narasi yang tidak begitu padat, ketepatan pengguanaan animasi, gambar, video yang tepat dan bermakna, serta variasi jenis, ukuran huruf yang jelas, (6) ilustrasi yang digunakan menarik, memotivasi, membantu pemahaman mahasiswa terhadap isi pesan, (7) kualitas rumusan soal-soal evaluasi yang meliputi kesesuaian soal dengan kompetensi, tingkat kesulitan soal, dan kejelasan rumusan soal.

Kualitas aspek pembelajaran meliputi: (3) kualitas pendahuluan yang meliputi standar kompetensi dan kompetensi dasar, (2) kualitas penyajian yang berupa uraian materi dan (3) keterlibatan serta peran mahasiswa.

Kualitas aspek tampilan produk multimedia interaktif meliputi: (1) kejelasan petunjuk, (2) keterbacaan teks, (3) kualitas tampilan gambar, (4) sajian animasi, (5) kejelasan suara dan narasi; (6) daya duk- 
ung musik dan (7) kemudahan dalam menjalankan software.

\section{Teknik Pengumpulan Data dan Instrumen}

Untuk menghasilkan produk pengembangan yang berkualitas diperlukan instrumen yang berkualitas dan mampu menggali apa yang dikehendaki dalam pengembangan produk pembelajaran multimedia interaktif. Instrumen yang digunakan untuk mengumpulkan data berupa kuesioner dan tes. Peneliti menggali data dengan instrumen yang sering digunakan oleh ahli lain atau terdapat dalam literaturliteratur yang ada serta divalidasi oleh ahli materi atau ahli media.

Instrumen yang digunakan dalam penelitian ini adalah: angket/kuisoner dan wawancara. Metode pengumpulan data dilakukan untuk: (1) menggali data mengenai ketepatan rancangan dan isi bahan ajar, peneliti melakukan diskusi produk multimedia dengan ahli materi yang disertai dengan lembar evaluasi untuk me-review dan memberikan komentar mengenai produk tersebut; (2) menggali data mengenai kualitas tampilan dan kualitas penyajian, digunakan angket dengan skala Likert, dan didiskusikan dengan ahli media serta responden uji coba satu lawan satu, kelompok kecil dan lapangan, (3) untuk menggali data mengenai kualitas produk dengan dilakukan dengan membandingkan hasil pretest dan post test pada saat uji coba lapangan.

\section{Teknik Analisis Data}

Data mengenai pendapat/tanggapan responden/siswa yang dikumpulkan melalui kuisioner dianalisis secara statistik deskriptif. Kritik dan saran konkrit yang dikemukakan responden dihimpun dan disarikan untuk memperbaiki program pembelajaran multimedia interaktif berbasis CDT untuk mata kuliah Jaringan Komputer.

Teknik analisis data kuantitatif dalam penelitian ini menggunakan analisis statistik dikriptif, yang berupa pernyataan sangat kurang, kurang, cukup, baik, sangat baik, sangat baik yang diubah menjadi data kuantitatif dengan skala 5 yaitu dengan penskoran dari 1 sampai 5. Langkah-langkah dalam analisis data antara lain: (1) mengumpulkan data kasar, (2) pemberian skor, (3) skor yang diperoleh kemudian dikonversikan menjadi nilai dengan skala 5 dengan menggunakan acuan konversi. Berdasarkan hasil konversi skor ke nilai maka diperoleh nilai produk multimedia pembelajaran yang sedang dikembangkan.

\section{Hasil Penelitian dan Pembahasan}

Dari hasil uji coba lapangan memberikan penilaian mengenai aspek pembelajaran dengan kriteria baik, dengan rerata skor 4,0 dari penilaian aspek pembelajaran dalam uji coba lapangan adalah baik.

Tabel dan diagram di bawah ini menunjukkan secara lebih jelas bahwa hasil penilaian yang diperoleh dari uji coba lapangan terhadap multimedia pembelajaran yang dikembangkan ditinjau dari aspek pembelajaran termasuk dalam kriteria "Baik" dengan rerata skor 4,0 .

Tabel 1. Distribusi Frekuensi Penilaian Aspek Pembelajaran pada Uji Coba Lapangan

\begin{tabular}{lcc}
\hline \multicolumn{1}{c}{ Kriteria } & Frekuensi & $\%$ \\
\hline Sangat baik & 2 & 20 \\
Baik & 8 & 80 \\
Cukup Baik & 0 & 0 \\
Kurang Baik & 0 & 0 \\
Sangat Kurang Baik & 0 & 0 \\
Jumlah & 10 & 100 \\
\hline
\end{tabular}

Tabel dan diagram diatas menunjukkan secara lebih jelas bahwa hasil penilaian yang diperoleh dari uji coba lapangan terhadap multimedia pembelajaran yang dikembangkan ditinjau dari aspek pembelajaran termasuk dalam kriteria "Baik" dengan rerata skor 4,0 .

Dari hasil analisis data di atas menunjukkan secara jelas bahwa mengenai kualitas multimedia yang sedang dikem- 
bangkan ini, dilihat dari aspek tampilan, aspek isi/materi, dan aspek pembelajaran adalah baik. Berikut skor yang diberikan oleh para mahasiswa untuk ketiga aspek secara lebih jelas dapat dilihat pada Tabel 2 dan diagram pada Gambar 1.

Tabel 2. Kualitas Produk Multimedia Pembelajaran Hasil Validasi Ahli Media

\begin{tabular}{lcc}
\hline Aspek Penilaian & Rerata Skor & Kriteria \\
\hline Aspek Tampilan & 3,5 & Baik \\
Aspek Isi/Materi & 3,7 & Baik \\
Aspek Pembelajaran & 4,0 & Baik \\
Jumlah Rerata & 11,2 & Baik \\
Rerata Keseluruhan & 3,73 & \\
\hline
\end{tabular}

Berdasarkan Tabel 2 dapat jelas terbaca bahwa rerata penilaian pada uji coba lapangan tentang kualitas multimedia adalah termasuk kategori "Baik". Rerata keseluruhan dari aspek tampilan, aspek pembelajaran dan isi/materi adalah 3,73.

Dari penilaian uji coba kelompok kecil dan uji coba lapangan dari aspek tampilan, aspek isi/materi dan aspek pembelajaran dapat disajikan dalam diagram batang pada Gambar 1.

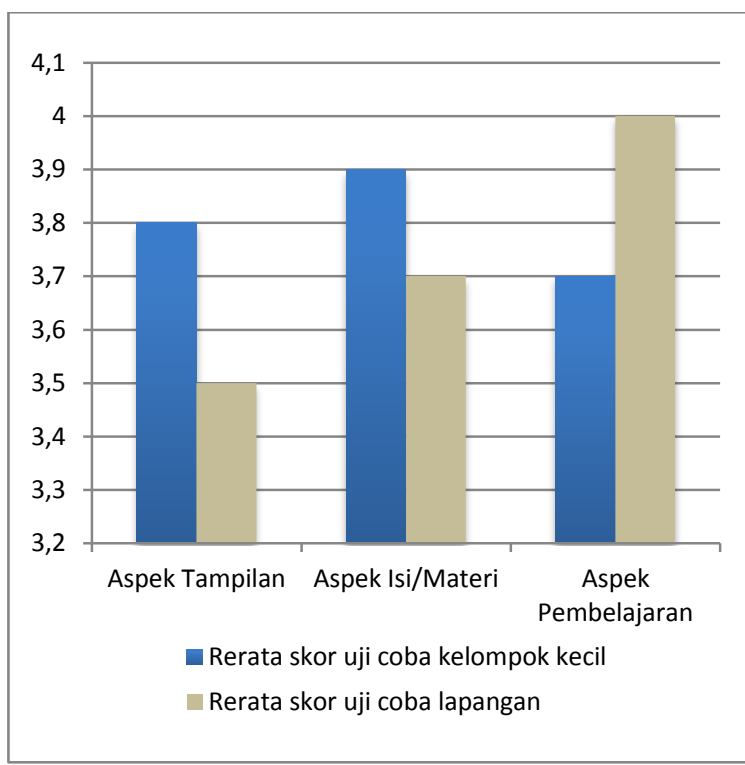

Gambar 3. Diagram batang penilaian multimedia pada uji coba kelompok kecil dan uji coba lapangan

\section{Simpulan dan Saran}

Simpulan

Produk berupa program pembelajaran multimedia interaktif Jaringan Komputer yang memiliki karakteristik sebagai berikut: (1) multimedia interaktif yang dalam perancangan dan pengembangannya menggunakan teori instruksional Component Display Theory (CDT) dan (2) penelitian ini merupakan penelitian dan pengembangan (research and development). Pengembangan multimedia ini dilakukan melalui tahapan: analisis, desain, pengembangan, evaluasi dan revisi. Setelah melalui tahap produksi dihasilkan produk awal yang divalidasi oleh ahli materi dan ahli media.

Kelayakan multimedia pembelajaran yang dikembangkan dari aspek isi/ materi, media dan pembelajaran berdasarkan penilaian dari ahli materi dan ahli media adalah memenuhi kriteria baik serta keseluruhan dari penilaian mahasiswa adalah "baik" yaitu ditunjukkan dengan besarnya rerata skor untuk setiap aspek penilaian pada aspek tampilan memiliki rerata skor 3,5, aspek isi/materi memiliki rerata skor 3,7 dan aspek pembelajaran memiliki rerata skor 4,0, Rerata skor keseluruhan sebesar 3,73 yang termasuk dalam kriteria "Baik", hal ini menunjukkan uji kelayakan program pembelajaran multimedia interaktif berbasis Component Display Theory (CDT) mata kuliah Jaringan Komputer sangat baik untuk mendukung belajar mandiri.

Saran

Berdasarkan kesimpulan dan keterbatasan di atas, didapatkan saran sebagai berikut: (1) produk multimedia ini dimanfaatkan dalam proses pembelajaran pada mata kuliah Jaringan Komputer pada Jurdik Matematika FMIPA UNY agar proses pembelajaran lebih mandiri, (2) produk multimedia ini disosialisasikan agar dapat dimanfaatkan oleh masyarakat luas khususnya pemerhati IT dan (3) dilakukan pengembangan materi secara keseluruhan sehingga akan meningkatkan kualitas ma- 
teri dan masih diperlukan perhatian dan upaya pengembangan-pengembangan media pembelajaran yang lebih bagus dan interaktif. Hal demikian dimaksudkan sebagai langkah aplikatif adaptif terhadap kemajuan ilmu, pengetahuan, dan teknologi untuk meningkatkan mutu pendidikan.

\section{Daftar Pustaka}

Fenrich, P.(1997). Practical guidelines for creating instructional multimedia applications. Fort Woth: The Dryden Press.
Gatot Pramono S. (2007). Aplikasi Component Display Theory Dalam Multimedia dan Web Pembelajaran. Pustekkom, Depdiknas. Technology. XX(8): 19-22.

Merrill. Paul F. et al. (1996) Computer in education ( $3^{\text {rd }}$ ed). Boston: Allyn \& Bacon.

Merrill, M.D. (1994). Instruction design theory. Englewood Cliffs: Educational Technology Publication. 